\title{
EVALUASI PENYELESAIAN SENGKETA PROSES PEMILIHAN UMUM DALAM PERSPEKTIF KONSTRUKSI HUKUMNYA
}

\author{
Jamil \\ Fakultas Hukum, Universitas Bhayangkara \\ e-mail: jamiljurist@gmail.com
}

\begin{abstract}
ABSTRAK
Ditinjau dari teori hukum, desain penyelesaian sengketa proses Pemilu banyak menemui ketidaksesuaian diantaranya adalah menyamakan pengaturan (hukum acara) antara sengketa proses Pemilu yang melibatkan pejabat tata usaha negara dengan yang tidak melibatkan pejabat tata usaha negara, proses upaya administrasi yang terlalu betele-tele, menempatkan Pengadilan Tata Usaha Negara sebagai pengadilan yang memiliki kewenangan (kompetensi) mengadili setelah melalui upaya administrasi di Bawaslu serta legal standing pemohon yang cenderung menegasikan hak konstitusional warga negara. Tulisan ini akan mengulas dan meluruskan desain penyelesaian sengketa proses Pemilu sebagaimana telah diatur dalam Undang-Undang Nomor 7 Tahun 2017 tentang Pemilihan Umum dan beberapa Peraturan Badan Pengawas Pemilu. Tulisan ini menggunakan pendekatan normatif dengan menganalisa peraturan perundang-undangan seperti Undang-Undang Pemilu dan peraturan-peraturan yang dikeluarkan Bawaslu, dengan cara disandingkan dengan teori hukum sebagai pisau analisis.
\end{abstract}

Kata Kunci: sengketa proses pemilu; Bawaslu; upaya administratif

\section{ABSTRACT}

Judging from the legal theory, the design of election process dispute resolution has encountered many discrepancies including the equalization of the regulation (procedural law) between election process disputes involving State administration officials and those that do not involve state administration officials, administrative effort processes that are too straightforward, placing The State Administrative Court as the court which has the authority (competence) to adjudicate after going through administrative efforts at Bawaslu and the legal standing of the applicant who tends to negate the constitutional rights of citizens. This paper will review and correct the design of election dispute resolution processes as regulated in Law Number 7 of 2017 concerning General Elections and several Election Oversight Regulations. This paper uses a normative approach by analyzing legislation such as the Election Law and regulations issued by Bawaslu, by juxtaposing it with legal theory as a knife of analysis.

Keywords: election process dispute; Bawaslu; administrative efforts

\section{PENDAHULUAN}

Salah satau wewenang dan fungsi peradilan (judicial function) yang dimiliki oleh Badan Pengawas Pemilu (Bawaslu), Bawaslu Provinsi, dan Bawaslu Kabupaten/Kota adalah menyelesaikan sengketa proses Pemilu melalui mediasi dan/atau sidang adjukasi. Wewenang tersebut secara lengkap diatur dalam Pasal 466 hingga Pasal 472 UndangUndang Nomor 7 Tahun 2017 tentang Pemilihan
Umum (selanjutnya disebut UU Pemilu). Aturan lebih reknis tentang penyelesaian sengketa proses Pemilu diatur dalam Peraturan Bawaslu (Perbawaslu).

Berkaitan dengan hal tersebut, Bawaslu sudah mengeluarkan Peraturan Bawaslu Nomor 18 Tahun 2017 tentang Tata Cara Penyelesaian Sengketa Proses Pemilihan Umum, Perbawaslu ini telah mengalami perubahan hingga perubahan ketiga yaitu Perbawaslu 
Nomor 18 Tahun 2018 sebagai perubahan pertama, Perbawaslu Nomor 27 Tahun 2018 sebagai perubahan kedua, dan Perbawaslu Nomor 5 Tahun 2019 sebagai perubahan ketiga atau terakhir selama pelaksanaan Pemilu 2019.

Berbekal dasar hukum di atas, Bawaslu, baik pusat hingga daerah Kabupaten/Kota telah banyak mengeluarkan putusan untuk menyelesaian sengketa proses Pemilu, dan eksistensi Putusan Bawaslu tersebut diakui dan diapresiasi oleh Mahkamah Konstitusi (Putusan MK No. 01/PHPU-PRES/ XVII/2019) karena mampu mengkanalisasi pelanggaran Pemilu dan efektif dalam meminimalisir gugatan di Mahkamah Konstitusi. Namun demikian, masih banyak hal yang perlu dievaluasi dari prestasi yang telah diraih oleh Bawaslu.

\section{PERUMUSAN MASALAH}

Evaluasi beberapa ketentuan yang mengatur tentang proses penyelesaian sengketa proses Pemilu baik proses yang ada di Bawaslu maupun yang ada di Pengadilan Tata Usaha Negara.

\section{PEMBAHASAN}

\section{Objectum Litis atas Sengketa Proses Pemilu}

Pasal 466 mendefiniskan sengketa proses Pemilu sebagai sengketa proses Pemilu yang meliputi sengketa yang terjadi antar peserta Pemilu dan sengketa peserta Pemilu dengan penyelenggara Pemilu sebagai akibat dikeluarkannya Keputusan KPU, Keputusan KPU Provinsi, dan Keputusan KPU Kabupaten/Kota.

Dari pengertian ini diperoleh beberapa subjectum litis atas sengketa proses Pemilu yaitu antar/sesama peserta Pemilu, dan peserta Pemilu dengan penyelenggara Pemilu. Sedangkan objectum litis atas sengketa tersebut hanyalah keputusan yang dikeluarkan KPU, KPU Provinsi, dan KPU Kabupaten/Kota (KPU/KPUD).

Sejatinya, apabila objek sengketanya berupa surat keputusan yang dikeluarkan KPU/KPUD maka salah satu pihak yang bersengketa (subjectum litis) pastilah badan yang mengeluarkan Surat Keputusan tersebut (KPU/KPUD), sedangkan KPU dalam hal ini adalah berkedudukan sebagai pejabat tata usaha negara. Dalam pengertian sengketa sebagaimana Pasal 466 UU Pemilu di atas, menjelasakan bahwa para pihak yang bersengketa terdiri dari: 1) Antar peserta Pemilu atau peserta Pemilu melawan sesama peserta Pemilu; 2) Peserta Pemilu melawan penyelenggara Pemilu.

Beranjak dari dua pengelompokan para pihak yang bersengketa tersebut maka sebenarnya yang memiliki objek sengketa (SK KPU) hanyalah kelompok kedua yaitu peserta Pemilu dengan penyelenggara Pemilu, sedangkan kelompok pertama (sengketa antar peserta Pemilu) tidak memiliki objek sengketa. Melihat kekosongan objek sengketa ini (rechtvacum), Bawaslu mengisinya dengan mengeluarkan Perbawaslu Nomor 18 tahun 2017 tentang Tata Cara Penyelesaian Sengketa Proses Pemilu, dalam Pasal 4 Perbawaslu tersebut diatur secara tegas tentang objek sengketa antar peserta Pemilu yaitu:

a. Perbedaan penafsiran atau suatu ketidakjelasan tertentu mengenai suatu masalah kegiatan dan/atau peristiwa yang berkaitan dengan pelaksanaan Pemilu sebagaimana diatur dalam ketentuan peraturan perundang-undangan;

b. Keadaan dimana terdapat pengakuan yang berbeda dan/atau penolakan/penghindaran antar peserta Pemilu; dan/atau

c. Keputusan KPU, keputusan KPU Provinsi, dan keputusan KPU Kabupaten/Kota.

Objek sengketa sebagaimana diatur dalam poin (a) dan (b) masih sangat sulit dipahami (membingungkan) dan sulit dipraktekkan, oleh karenanya dalam Perbawaslu Nomor 18 Tahun 2018 perubahan pertama atas Perbawaslu Nomor 17 Tahun 2018 objek sengketa yang diatur dalam perbawaslu Nomor 17 Tahun 2018 tidak muncul lagi sehingga Pasal 4 hanya mengatur hal sebagai berikut:

(1) Objek sengketa meliputi keputusan KPU, keputusan KPU Provinsi, atau keputusan KPU Kabupaten/Kota;

(2) Keputusan KPU, Keputusan KPU Provinsi, atau Keputusan KPU Kabupaten/Kota sebagaimana dimaksud pada ayat (1) dalam bentuk surat keputusan dan/atau berita acara.

Penghapusan pengaturan objek sengketa dalam Perbawaslu Nomor 18 Tahun 2018 kembali memunculkan kekosongan hukum atas objek sengketa antar peserta Pemilu, sehingga sengketa antar peserta Pemilu hanya termaktub dalam UU Pemilu tetapi karena objek sengketanya tidak diatur lebih lanjut dalam perundang-undangan yang lebih teknis, (Perbawaslu) maka sengketa antar 
peserta Pemilu tidak pernah ada atau tidak pernah diselesaikan melalui mekanisme apapun di Bawaslu.

Dalam perbawaslu Nomor 27 Tahun 2018 perubahan kedua atas Perbawaslu Nomor 18 Tahun 2017 masih tetap tidak mengatur objek sengketa antar peserta Pemilu karena Pasal 4 yang mengatur tentang objek sengketa tidak mengalami perubahan, sehingga meskipun Perbawaslu sudah mengalami perubahan dua kali kekosongan hukum atas objek sengketa antar peserta Pemilu tetap menjadi problem.

Pada tahun 2019 Bawaslu kembali mengeluarkan Perubahan yang ketiga atas Perbawaslu Nomor 18 Tahun 2017 yaitu Perbawaslu Nomor 5 Tahun 2019. Dalam perbawaslu tersebut objek sengketa antar peserta Pemilu kembali muncul dalam Pasal 4 tetapi berbeda redaksi yaitu berbunyi sebagai berikut:

(1) Sengketa proses Pemilu sebagaimana dimaksud dalam Pasal 3 terjadi karena:

a. Hak peserta Pemilu yang dirugikan secara langsung oleh tindakan peserta Pemilu lain; atau

b. Hak peserta Pemilu yang dirugikan secara langsung oleh tindakan KPU, KPU Provinsi, atau KPU Kabupaten/Kota, sebagai akibat dikeluarkannya keputusan KPU, keputusan KPU Provinsi, atau keputusan KPU Kabupaten/Kota.

(2) Keputusan KPU, keputusan KPU Provinsi, atau keputusan KPU Kabupaten/Kota sebagaimana dimaksud pada ayat (1) berupa surat keputusan dan/atau berita acara.

Penyelesaian atas sengketa proses Pemilu dapat ditangani oleh Panwascam sebagai penerima mandat dari Bawaslu kabupaten/Kota (Pasal 4 ayat (4)). Penyelesaian sengketa antar peserta dilakukan melalui mediasi dan apa bila tidak terdapat kesepakatan Bawaslu dapat langsung mengeluarkan putusan tanpa sidang adjudikasi. Mekanisme ini dikenal dengan penyelesaian sengketa cepat.

Pengaturan objek sengketa melalui Perbawaslu yang berubah-ubah menunjukkan betapa tidak mudahnya dalam menindaklanjuti aturan teknis atas rumusan sengketa proses Pemilu antar peserta Pemilu sebagaimana diatur dalam UU Pemilu. Bawaslu nampaknya sangat kebingungan dalam mengisi kekosongan objek sengketa antar peserta Pemilu yang tidak diatur dalam UU Pemilu, sehingga pengaturan objek sengketa dalam Perbawaslu muncul tenggelam dan berubah-ubah.

Bagi penulis, problem itu terjadi karena kesalahan UU Pemilu dalam merumuskan sengketa proses Pemilu. Kesalahan itu bermuara dari rumusan sengketa proses Pemilu yang tidak membedakan antara subjek hukum yang berkedudukan sebagai pejabat tata usaha negara dengan subjek hukum yang bukan pejabat tata usaha negara. KPU adalah subjek hukum yang berkedudukan sebagai pejabat tata usaha negara yang pengaturannya seharusnya tunduk pada hukum administrasi apabila menjadi salah satu pihak dalam sengketa sedangkan apabila sengketa terjadi antar peserta Pemilu yang notabene tidak ada yang berkedudukan sebagai pejabat tata usaha negara seharusnya tunduk pada hukum perdata.

Hakikatnya sengketa itu memang memiliki karakter keperdataan, namun apabila salah satu pihak yang bersengketa berkedudukan sebagai Pejabat Tata Usaha Negara dan objek sengketanya berupa surat keputusan Pejabat Tata usaha Negara (SK KPU/ KPUD), maka tidak boleh tidak harus tunduk pada hukum administrasi, karena tindakan yang dilakukan oleh pejabat Tata Usaha Negara baik yang berupa tindakan kongrit (materiele daad) maupun berupa mengeluarkan surat keputusan (policy) merupakan tindakan dalam rangka menjalankan programprogram negara sehingga memiliki karakter hukum yang berbeda bila dibandingkan dengan sengketa antar atau sesama masyarakat sipil.

Menurut Sudikno Mertokusumo, Perbuatan perseorangan digerakkan oleh kepentingan diri sendiri (pribadi), sedangkan tindakan pemerintah (Pejabat Tata Usaha Negara) itu mempunyai latar belakang kepentingan umum. ${ }^{1}$ Dalam menjalankan tugas-tugasnya, pemerintah boleh mengambil segala tindakan-tindakan yang dianggapnya perlu untuk menyelenggarakan tugasnya, oleh karena itu, supaya dapat melaksanakan tugasnya dengan sempurna, pemerintah memerlukan kebebasan dalam tindakan-tindakannya, tetapi sebaliknya, harus diingat bahwa besar kemungkinannya, bahkan sering terjadi bahwa kepentingan perorangan terlanggar karena penyelahgunaan wewenang oleh pemerintah. ${ }^{2}$

\footnotetext{
${ }^{1}$ Sudikno Mertokusumo. (2019). Perbuatan Melawan Hukum oleh Pemerintah. Yogyakarta: Maha Karya Pustaka, h. 64.

${ }^{2}$ ibid.
} 
Berdasar perbedaan karakter di atas, sudah selayaknya sengketa proses antar peserta Pemilu dan sengketa proses antara penyelenggara Pemilu dengan peserta Pemilu diatur melalui pendekatan yang sesuai dengan karakternya masing-masing. Sengketa antar peserta menggunakan pendekatan hukum perdata (onrechtmatige daad) sedangkan sengketa antara penyelenggara Pemilu dengan peserta Pemilu menggunakan pendekatan hukum administrasi.

\section{Upaya Administratif dalam Penyelesaian Sengketa Proses Pemilu}

Terdapat banyak istilah dalam mengungkapkan Upaya Administratif diantaranya adalah administrative beroep, quasi rechtspraak, peradilan administrasi semu, dan lain-lain. Banyaknya istilah tersebut karena masing-masing akademisi memiliki perbedaan perspektif dalam merumuskannya. ${ }^{3}$ Undang-Undang Nomor 30 tahun 2014 tentang Administrasi Pemerintahan merumuskan Upaya Administratif sebagai proses penyelesaian sengketa yang dilakukan dalam lingkungan Administrasi Pemerintahan sebagai akibat dikeluarkannya Keputusan dan/atau Tindakan yang merugikan. Wewenang Bawaslu dalam menyelesaikan sengketa proses Pemilu melalui Upaya Administratif secara expresis verbis ditegaskan dalam Pasal $471 \mathrm{UU}$ Pemilu.

Menurut R. Wiyono sebagaimana dikutip oleh Ridwan, Upaya Administratif merupakan dan dimaksudkan sebagai control atau pengawasan yang bersifat intern dan represif di lingkungan Tata Usaha Negara terhadap keputusan yang dikeluarkan oleh Badan atau Pejabat Tata Usaha Negara terhadap keputusan yang dikeluarkan oleh badan atau pejabat Tata Usaha Negara. ${ }^{4}$ Sedangkan menurut SF Marbun, Pengawasan intern melalui Upaya Adminsitratif ini perlu dilakukan, kecuali untuk menghindari agar kekuasaan dan kebebasan yang diberikan kepada administrasi negara tidak disalahgunakan, juga dimaksudkan untuk memberikan perlindungan hukum. Perlindungan hukum melalui upaya administratif, dimaksudkan untuk memberikan

${ }^{3}$ S.F. Marbun. (2003). Peradilan Administrasi dan Upaya Administratif di Indonesia. Cetakan Kedua. Yogyakarta: UII Press, h. 51

4 Ridwan. (2019). Urgensi Upaya Adminsitratif di Indonesia. Yogyakarta: FH UII Press, h. 19. perlindungan hukum bagi warga negara yang dirugikan oleh sikap tindak administrasi negara, juga terhadap administrasi negara sendiri yang dalam melaksanakan tugas dan fungsinya secara benar dan sesuai dengan hukum.

Langkah upaya administratif sebenarnya dapat dilakukan untuk semua sengketa administrasi antara pejabat tata usaha negara dengan warga masyarakat atas surat keputusan yang dikeluarkan pejabat tata usaha negara, namun karena hukum acaranya belum tersedia secara lengkap, maka upaya administratif ini kurang populer di dunia penegakan hukum Indonesia. Upaya Administrasi hanya terjadi pada sengketa yang disediakan lembaga khusus untuk menyelesaikannya melalui jalur upaya administratif seperti lembaga Bawaslu yang oleh Pasal 471 UU Pemilu diberi kewenangan untuk menyelesaiakan sengketa Pemilu melalui upaya administrasi sebelum mengajukan gugatan ke Pengadilan Tata Usaha Negara. Kewajiban menempuh langkah upaya administrasi bagi sengketa administrasi yang tersedia lembaga khusus ini juga ditegaskan dalam Pasal 48 UU No. 5 Tahun 1986 tentang Peradilan Tata Usaha Negara (UU PTUN).

(1) Dalam hal suatu Badan atau Pejabat Tata Usaha Negara diberi wewenang oleh atau berdasarkan peraturan perundang-undangan untuk menyelesaikan secara administratif sengketa Tata Usaha Negara tertentu, maka sengketa Tata Usaha Negara tersebut harus diselesaikan melalui upaya administratif yang tersedia;

(2) Pengadilan baru berwenang memeriksa, memutus, dan menyelesaikan sengketa Tata Usaha Negara sebagaimana dimaksud dalam ayat (1) jika seluruh upaya administratif yang bersangkutan telah digunakan.

Atas dasar hal tersebut di atas hakikatnya sengketa proses Pemilu antara KPU dengan peserta Pemilu menjadi Kompetensi Absolute dari peradilan Tata Usaha Negara, namun harus menggunakan upaya administratif terlebih dahulu di Bawaslu sebelum ke Pengadilan Tata Usaha Negara.

Namun demikian penulis melihat ada inkonsistensi dalam menempatkan Bawaslu sebagai lembaga yang menyelesaikan sengketa melalui upaya administratif sebelum ke Pengadilan Tata Usaha Negara, karena Pasal 469 UU Pemilu hanya menempatkan Bawaslu sebagai lembaga yang 
menyelesaikan sengketa melalui upaya administratif hanya pada kasus-kasus tertentu saja yaitu putusan terhadap sengketa proses Pemilu yang berkaitan dengan (1) verilikasi Partai Politik Peserta Pemilu, (2) penetapan daftar calon tetap anggota DPR, DPD, DPRD Provinsi, dan DPRD Kabupaten/Kota; dan (3) penetapan Pasangan Calon. Sedangkan putusan selain tiga hal tersebut bersifat final dan mengikat sehingga karena putusannya sudah final dan mengikat Bawaslu tidak lagi menjadi lembaga yang menyelesaikan melalui upaya administratif tetapi sudah berperan sebagai pengadilan murni.

Selain tidak konsisten dalam memposisikan Bawaslu sebagai lembaga yang menyelesaikan sengketa melalui upaya administratif, hal lain yang menurut penulis harus di evaluasi adalah dualisme mekanisme penyelesian sengketa antara mediasi dan adjudikasi. Dualisme penyelesaian sengketa proses Pemilu tersebut secara expresis verbis ditegaskan dalam Pasal 468 ayat (3) UU Pemilu:

Bawaslu, Bawaslu Provinsi, Bawaslu Kabupaten/ Kota melakukan penyelesaian sengketa proses Pemilu melalui tahapan:

a. Menerima dan mengkaji permohonan penyelesaian sengketa proses Pemilu; dan

b. Mempertemukan pihak yang bersengketa untuk mencapai kesepakatan melalui mediasi atau musyawarah dan mufakat.

Dalam hal tidak tercapai kesepakatan antara pihak yang bersengketa sebagaimana dimaksud pada ayat (3) nomor b, Bawaslu, Bawaslu Provinsi, Bawaslu Kabupaten/Kota menyelesaikan sengketa proses Pemilu melalui adjudikasi.

Dualisme penyelesaian sengketa ini menurut penulis terlalu bertele-tele (berlarut-larut) untuk ukuran penyelesaian sengketa dengan cara upaya administratif, seharusnya metode penyelesaian sengketa melalui upaya adminsitrasi ini dapat dibuat sesederhana mungkin dengan satu metode saja karena penyelesaian dengan cara upaya administrasi merupakan metode penyelesaian sengketa sebelum ke pengadilan yang berfungsi untuk meminimalisir menumpuknya gugatan ke Pengadilan Tata Usaha Negara, oleh karenanya menurut penulis sebaiknya mekanisme penyelesaiannya dibuat sederhana saja dengan satu mekanisme.

Penyelesaian sengketa melalui wadah atau sarana upaya administrasi dengan mengutamakan cara musyawaroh akan memperoleh wadah, karena lebih sesuai dengan semangat kehidupan masyarakat Indonesia, yakni semangat kekeluargaan, gotong royong, hidup rukun dan damai serta kompromistis. Disinilah posisi strategis upaya administratif akan sangat dirasakan manfaatnya, sehingga eksistensinya semakin diperlukan untuk meminimalkan munculnya sengketa administrasi di hadapan peradilan administrasi, dimana badan atau pejabat administrasi akan berhadapan dengan rakyat secara konfrontatif. ${ }^{5}$

Beranjak dari keterangan pada paragraph di atas, mekanisme mediasi dalam penyelesaian sengketa memiliki dasar teori yang cukup argumentatif dan dapat dipertanggungjawabkan secara akademik, namun penulis lebih merekomendasikan penggunaan metode adjudikasi demi menghindari komprami yang melanggar perundang-perundangan dalam penyelesaian sengketa proses Pemilu.

\section{Kompetensi Absolut Peradilan Tata Usaha Negara}

Kewenangan pengadilan dalam mengadili suatu perkara tertentu dikenal dengan istilah kompetensi pengadilan. Kompetensi pengadilan ada dua yaitu kompetensi absolute dan kompetensi relative. Sudikno Mertokusumo mengartikan kompetensi absolute sebagai wewenang badan pengadilan dalam memeriksa jenis perkara tertentu yang secara mutlak tidak dapat diperiksa oleh badan pengadilan lain, baik dalam lingkungan peradilan yang sama maupun dalam lingkungan peradilan lain. ${ }^{6}$ Sedangkan kompetensi relative berkaitan dengan wilayah hukum badan peradilan.

Banyak metode dalam menentukan kompetensi pengadilan dalam mengadili suatu perkara tetapi yang paling populer adalah dilihat dari kriteria objek sengketanya. Bila dilihat dari kriteria objek sengketa yang berupa surat keputusan KPU, maka yang memiliki kompetensi adalah pengadilan Tata Usaha Negara, akan tetapi yang menjadi pertanyaan adalah pengadilan Tata Usaha Negara tingkat yang mana yang memiliki kompetensi untuk mengadili sengketa proses Pemilu setelah dilakukan upaya administrasi di Bawaslu?

\footnotetext{
${ }^{5}$ S.F Marbun. op.cit., h. 60.

${ }^{6}$ Priyatmanto Abdoellah. (2016). Revitalisasi Kewenangan PTUN, Gagasan Perluasan Kompetensi Peradilan Tata Usaha Negara. Yogyakarta: Cahaya Atma Pustaka, h. 102.
} 
Pasal 469 ayat (2) UU Pemilu, memberikan kewenangan kepada Pengadilan Tata Usaha Negara untuk mengadili segketa Proses Pemilu setelah dilakukan upaya administrasi di Bawaslu, yaitu "Dalam hal penyelesaian sengketa proses Pemilu sebagaimana dimaksud pada ayat (1) huruf a, huruf $b$, dan huruf $c$ yang dilakukan oleh Bawaslu tidak diterima oleh para pihak, para pihak dapat mengajukan upaya hukum kepada Pengadilan Tata Usaha Negara."

Hal ini menurut penulis kurang tepat karena sama halnya proses penyelesaian sengketa di Bawaslu yang dilakukan melalui sidang mediasi dan adjudikasi tidak diperhitungkan atau dianggap tidak pernah ada proses penyelesaian melalu upaya adminsitrasi di Bawaslu. Oleh karenanya Pasal 51 ayat (3) UndangUndang Nomor 5 Tahun 1986 tentang Peradilan Tata Usaha Negara (UU PTUN) memberikan kewenangan kepada Pengadilan Tinggi Tata Usaha Negara bagi sengketa yang sudah dilakukan proses pemeriksaan melalui lembaga khusus (Bawaslu) yang disediakan untuk menyelesaikan dengan cara upaya administrasi sebagaimana yang ditaati oleh Pasal 154 UndangUndang Nomor 1 Tahun 2015, yaitu "Pengajuan gugatan atas sengketa tata usaha negara Pemilihan ke Pengadilan Tinggi Tata Usaha Negara dilakukan setelah seluruh upaya administratif di Bawaslu Provinsi dan/atau Panwas Kabupaten/Kota telah dilakukan."

\section{Legal Standing Pemohon (Subjectum Litis)}

Bagi penulis persoalan legal standing merupakan persoalan yang penting karena berkaitan dengan hak konstitusional seseorang dalam mendapatkan hak-haknya. Jangan sampai hak konstitusional seseorang terhalang karena persoalan formil yang tidak terpenuhi. Beranjak dari hal tersebut, Pasal 467 menegaskan bahwa Permohonan penyelesaian sengketa proses Pemilu disampaikan oleh calon peserta Pemilu dan/atau peserta Pemilu. Sedangkan pengertian peserta Pemilu sebagaimana dijelaskan dalam Pasal 1 ayat (27) UU Pemilu terdiri dari (1) Partai Politik untuk Pemilu anggota PPR, anggota DPRD provinsi, anggota DPRD kabupaten/kota, (2) Perseorangan untuk Pemilu anggota DPD, dan (3) Pasangan calon yang diusulkan oleh Partai Potitik atau Gabungan Partai Politik untuk Pemilu presiden dan Wakil Presiden.
Perbawaslu mengatur lebih detail tentang legal standing pemohon ini. Dalam Pasal 7 Perbawaslu Nomor 18 Tahun 2017 dijelaskan secara terperinci pemohon yang memiliki legal standing dalam mengajukan permohonan di Bawaslu (Subjectum Litis) yaitu terdiri dari:

a. Partai politik calon Peserta Pemilu yang telah mendaftarkan diri sebagai Peserta Pemilu di KPU;

b. Partai Politik Peserta Pemilu;

c. Calon anggota DPR dan DPRD yang tercantum dalam daftar calon sementara;

d. Calon anggota DPR dan DPRD yang tercantum dalam DCT;

e. Gabungan Partai Politik Peserta Pemilu;

f. Bakal calon Anggota DPD yang telah mendaftarkan diri kepada KPU;

g. Calon anggota DPD;

h. Bakal Pasangan Calon; dan

i. Pasangan Calon.

Ketentuan dalam Pasal 7 Perbawaslu Nomor 18 Tahun 2017 sebagaimana dijelaskan di atas, mengalami perubahan pada Perbawaslu Nomor 18 Tahun 2018. Dalam Perbawaslu Nomor 18 Tahun 2018, Calon anggota DPR dan DPRD yang tercantum dalam Daftar Calon Sementara (DCS) dan Gabungan Partai Politik Peserta Pemilu tidak dicantumkan sebagai subjek hukum yang memiliki legal standing bersengketa di Bawaslu.

Perbawaslu Nomor 27 Tahun 2018 tentang Perubahan Kedua Atas Perbawaslu Nomor 18 Tahun 2017 tentang Tata Cara Penyelesaian Sengketa Proses Pemilihan Umum, memunculkan legal standing baru yaitu "Bakal calon anggota DPR dan DPRD yang telah mendaftarkan diri kepada KPU”, Subjek hukum ini menurut penulis merupakan perluasan dari Calon anggota DPR dan DPRD yang tercantum dalam daftar calon sementara (DCS) yang termaktub dalam Pasal 7 huruf c Perbawaslu Nomor 18 Tahun 2017 yang kemudian dihapus oleh Perbawaslu Nomor 18 Tahun 2018.

Dari ketentuan sebagaimana dalam perbawaslu yang sudah berubah hingga tiga kali perubahan tersebut, terdapat dua subjek hukum yang memiliki legal standing dalam mengajukan permohonan di Bawaslu yaitu subjek hukum berupa badan hukum (rechts person) seperti Partai Politik dan gabungan Partai Politik dan orang (person) yaitu calon anggota 
DPR, DPRD, DPD, dan pasangan calon. Namun demikian menempatkan subjek hukum person untuk calon anggota DPR dan DPRD nampaknya masih setengah hati karena dalam Pasal 7B Perbawaslu Nomor 18 Tahun 2018 masih dibebani syarat diwakli oleh partai politik yang mengusungnya.

Bakal calon anggota DPR, DPRD Provinsi, DPRD Kabupaten/kota yang tidak ditetapkan sebagai daftar calon sementara anggota DPR, DPRD Provinsi, DPRD Kabupaten/kota dapat mengajukan permohonan penyelesaian sengketa proses Pemilu yang diwakili oleh partai politik sesuai tingkatannya.

Bakal Calon anggota DPR, DPRD Provinsi, dan DPRD Kabupaten/kota yang tercantum dalam daftar calon sementara tidak ditetapkan oleh KPU, KPU Provinsi, dan KPU Kabupaten/Kota sebagai DCT anggota DPR, DPRD Provinsi, DPRD Kabupaten/ kota dapat mengajukan permohonan penyelesaian sengketa proses Pemilu yang diwakili oleh partai politik sesuai tingkatannya.

Bagi penulis keharusan diwakili oleh partai politik ini seharusnya tidak perlu ada bagi calon anggota DPR dan DPRD yang sudah terdaftar dalam Daftar Calon Tetap (DCT), karena sesungguhnya ketika calon anggota DPR dan DPRD yang sudah terdaftar sebagai calon oleh KPU (masuk DCT) maka yang bersangkutan sudah bisa berdiri sendiri sebagai subjek hukum dengan segala hak dan kewajiban yang melekat padanya, diantaranya adalah hak konstitusional dalam mengajukan permohonan sengketa di Bawaslu, terlebih lagi pasca Putusan MK No. 22-24/PUU-VI/2008 sistem pemilihan anggota DPR dan DPRD tidak lagi berdasarkan nomor urut melainkan didasarkan pada suara terbanyak yang dikenal dengan sistem proporsional terbuka. Atas dasar hal tersebut calon anggota DPR dan DPRD yang sudah masuk dalam DCT semestinya sudah memiliki legal standing sendiri dalam mengajukan permohonan sengketa proses Pemilu.

Pemberian legal standing yang setengah hati hampir sama dengan konstruksi Peraturan Mahkamah Konstitusi Nomor 2 Tahun 2018, yang menentukan Pemohon sengketa hasil di Mahkamah Konstitusi terdiri dari:

a. Partai Politik Peserta Pemilu untuk pengisian keanggotaan DPR dan DPRD; b. Perseorangan calon anggota DPR dan DPRD dalam satu Partai Politik yang sama yang telah memeroleh persetujuan secara tertulis dari ketua umum dan sekretaris jenderal atau sebutan lainnya dari Partai Politik yang bersangkutan;

c. Partai Politik Lokal peserta Pemilu untuk pengisian keanggotaan DPRA dan DPRK;

d. Perseorangan calon anggota DPRA dan DPRK dalam satu Partai Politik Lokal yang sama yang telah memeroleh persetujuan secara tertulis dari ketua umum dan sekretaris jenderal atau sebutan lainnya dari Partai Politik Lokal yang bersangkutan;

Dalam Pasal 3 Huruf $b$ dan d Peraturan Mahkamah Konstitusi No. 2 Tahun 2018 tersebut di atas, perseorangan anggota DPR, DPRD, dan Perseorangan calon anggota DPRA dan DPRK dalam satu partai politik memiliki legal standing untuk mengajukan permohonan perselisihan hasil Pemilu namun harus memperoleh persetujuan secara tertulis dari ketua umum atau sekretaris jendral partai pengusungnya. Terhadap ketentuan tersebu Refly Harun juga mengatakan adanya pemberian legal standing "setengah hati" kepada pemohon perseorangan calon anggota DPR dan DPRD. ${ }^{7}$

Beranjak dari problem di atas, penulis mengusulkan adanya ketegasan legal standing yang diberikan kepada calon anggota DPR dan DPRD yang sudah masuk DCT untuk mengajukan permohonan sengketa proses Pemilu. Penegasan legal standing tersebut tidak hanya dalam aturan level Perbawaslu tetapi dalam level undang-undang.

\section{PENUTUP \\ Kesimpulan}

Konstruksi desain penyelesaian sengketa proses Pemilu, seharusnya sesuaikan dengan teori-teori hukum yang sudah baku, tujuannya selain untuk mencapai kepastian, keadlian dan kemanfaatan hukum juga untuk memelihara teori hokum itu sendiri agar tidak punah karena dikhianati oleh rumusan perundang-undangan dalam tataran dogmatika hukum. Teori hukum tentunya usdah dirancang melalui berbagai kajian mendalam yang disesuaikan dengan efektifitas dalam mencapai tujuan hukum

\footnotetext{
${ }^{7}$ Refly Harun. (2019). Hukum sengketa Pemilu, Mekanisme Penyelesaian Perselisihan Hasil Pemilu di Mahkamah Konstitusi. Jakarta: Konstitusi Press, h. 58.
} 
sendiri oleh karenanya mentaatinya merupakan cara yang paling tepat dalam merumuskan perundangundangan.

\section{Rekomendasi}

1. Membedakan pengaturan sengketa proses Pemilu antara sengketa yang melibatkan pejabat tata usaha negara dengan yang tidak melibatkan pejabat tata usaha negara. Bila salah satu pihak yang bersengketa adalah pejabata tata usaha negara dan berkaitan kewenangan sang pejabat maka seharusnya mengikuti konsepsi hukum administrasi tetapi apabila yang bersengketa sama-sama di luar pejabat tata usaha negara (masyarakat sipil) maka tunduk pada konsepsi hukum perdata;

2. Proses pemeriksaan hanyalah upaya admnistrasi sebelum ke pengadilan tata usaha negara oleh karenanya sebaikanya tidak terlalu banyak menggunakan metode;

3. Upaya hukum setelah melalui proses upaya administrasi di Bawaslu seharusnya kompetensinya diberikan ke Pengadilan Tinggi Tata Usaha Negara;

4. Mempertegas legal standing pemohon sengketa dalam tingkat undang-undang.

\section{DAFTAR PUSTAKA}

\section{Peraturan Perundang-undangan:}

Undang-Undang Nomor 5 Tahun 1986 tentang Peradilan Tata Usaha Negara.

Undang-Undang Nomor 7 Tahun 2017 tentang Pemilihan Umum.

Peraturan Bawaslu Nomor 5 Tahun 2019 tentang Tata Cara Penyelesaian Sengketa Proses Pemilihan Umum, perubahan ketiga dari Peraturan Bawaslu Nomor 5 Tahun 2019 tentang Tata Cara Penyelesaian Sengketa Proses Pemilihan Umum.

Peraturan Mahkamah Konstitusi Nomor 2 Tahun 2018.

Putusan Mahkamah Konstitusi No. 01/PHPU-PRES/ XVII/2019.

\section{Buku:}

Priyatmanto Abdoellah. (2016). Revitalisasi Kewenangan PTUN, Gagasan Perluasan Kompetensi Peradilan Tata Usaha Negara. Yogyakarta: Cahaya Atma Pustaka.

Refly Harun. (2019). Hukum sengketa Pemilu, Mekanisme Penyelesaian Perselisihan Hasil Pemilu di Mahkamah Konstitusi. Jakarta: Konstitusi Press.

Ridwan. (2019). Urgensi Upaya Adminsitratif di Indonesia. Yogyakarta: FH UII Press.

S.F. Marbun. (2003). Peradilan Administrasi dan Upaya Administratif di Indonesia. Cetakan Kedua. Yogyakarta: UII Press.

Sudikno Mertokusumo. (2019). Perbuatan Melawan Hukum oleh Pemerintah. Yogyakarta: Maha Karya Pustaka. 